\title{
Exploración de los estilos de aprendizaje de inglés y la asimilación del conocimiento del estudiante
}

\section{Exploration of learning styles of english subject in the student's knowledge assimilation}

Abigail Dioselina Garrido Valle. ${ }^{1}$, Elsa Amalia Basantes Arias. ${ }^{2}$ \& María Guadalupe Escobar Murillo. ${ }^{3}$

Recibido: 10-12-2019 / Revisado: 26-12-219 /Aceptado: 04-01-2020/ Publicado: 07-02-2020

\begin{abstract}
.
DOI: $\underline{\text { https://doi.org/10.33262/concienciadigital.v3i1.1.1129 }}$

The present research was to determine, identify, analyze and establish the learning styles applied in the assimilation of knowledge of the English Language subject; taking into account that their lack of knowledge creates difficulties both in the development of the subject and in the generation of significant learning of the students of the Ninth and Tenth Level of Basic General Education of the Educational Unit "Liceo Policial Chimborazo" during the 20152016 school year in the city of Riobamba. This study was qualitative, exploratory, bibliographic and field type. The qualitative method used was ethnographic, the same method that allowed the study to be carried out in a direct and natural context. For data collection, the observation technique was used and as an instrument a tab that was prepared by a group of expert collaborators in the area. The instrument was validated and applied to students and teachers. The tabulated, analyzed and interpreted data allowed to conclude that the predominant style of learning in the group of students analyzed, was the reflexive pragmatist that positively influenced the learning - teaching process for assimilation English Language knowledge.
\end{abstract}

Keywords: Exploration, Learning Styles, Knowledge Assimilation, English

1 Escuela Superior Politécnica de Chimborazo, Facultad de Ciencias, Morona Santiago, Ecuador, abigail.garrido@espoch.edu.ec

2 Escuela Superior Politécnica de Chimborazo, Facultad de Salud Pública, Riobamba, Ecuador, elbasantes@espoch.edu.ec

3 Escuela Superior Politécnica de Chimborazo, Facultad de Salud Pública, Riobamba, Ecuador, maria.escobar@espoch.edu.ec

Creatividad, Diseño e Innovación

Página 17 


\section{Resumen.}

La presente investigación fue determinar, identificar, analizar y establecer los estilos de aprendizaje aplicados en la asimilación de conocimientos de la asignatura del Idioma Ingles; teniendo en consideración que su desconocimiento genera dificultades tanto en el desarrollo de la asignatura como en la generación de un aprendizaje significativo de los estudiantes del Noveno y Décimo Nivel de Educación General Básica de la Unidad Educativa "Liceo policial Chimborazo" durante el año lectivo 2015-2016 en la ciudad de Riobamba. Este estudio fue de tipo cualitativo, de nivel exploratorio, bibliográfico y de campo. El método cualitativo empleado fue el etnográfico, el mismo que permitió realizar el estudio en un contexto directo y natural. Para la recolección de datos se utilizó la técnica de la observación y como instrumento una ficha que fue elaborada por un grupo de colaboradores expertos en el área. El instrumento fue validado y aplicado a los estudiantes y docentes. Los datos tabulados, analizados e interpretados permitieron concluir que el estilo de aprendizaje predominante en el grupo de estudiantes analizado, fue el pragmático reflexivo que influyó de manera positiva en el proceso de enseñanza aprendizaje para la asimilación de conocimientos del Idioma Inglés.

Palabras claves: Exploración, Estilos de aprendizaje, Asimilación del conocimiento, Inglés

\section{Introducción.}

The propose of this research is to explore why teachers and students do not know the learning styles to obtain a good knowledge's assimilation during the learning process in Noveno and Décimo año de Educación Básica at Unidad Educativa "Liceo Policial Chimborazo". This study is to observe why the students do not use the learning styles to acquire relevant or true information that let them to increase their knowledge so obtain a significant learning to be competitive as a good student in different educational necessities and the other hand teachers can use correct methods, techniques and materials.

The problem is caused by teachers and students unknown the learning styles so students have limited use of their sense and skills, inactive participation; these are the main causes of which teacher detect the learning style is so important for students assimilate the knowledge in a best way. This problem is caused, first because teachers do not know how detect the learning styles of each one their students. Second teachers do not use the correct methods and techniques according students' learning styles for increasing the knowledge of students and finally students do not know what is their learning style for a good assimilation of knowledge into the English subject.

Once reviewed the library's files of the Facultad de Ciencias de la Educación, Humanas y tecnologías at UNACH and, it was verified that there are not similar researches, but there is 
one research, which has similar variables it is: "Análisis de los estilos de aprendizaje del idioma inglés en los alumnos de primer año de bachillerato del Colegio, Capitán Edmundo Chiriboga, años 2012-2013." By: Jessica Poma and RinaVizuete, 2014. (Universidad Nacional de Chimborazo).

This project's objective is to analyze the learning styles so it helps the intellectual, effectiveness, and social necessities. To improve the best development in the interaction process at English language. This research is based in the Kolb's model (active reflexive, theory, pragmatic) honey and Alonso too. They explain clearly way about learning styles.

"Student learning style adaptation method based of teaching strategies and electronic media" By: Ana Lidia Franzoni, 2009. (Instituto Tecnológico Autónomo de Mexico). This research's objective is to know the different learning styles and that students apply the learning styles to solve various problems according their learning necessities. The learning styles are combined with an appropriate teaching of teacher to improve their skills during the learningteaching process.

Kneefe (1988) says that, learning styles is the composite of characteristic, cognitive, affective, and physiological factors that use as stablished pointers of how a student acquires and interacts the new knowledge and practice in any environment. It shows which models of mood and development throught which students demonstrate the good schooling and better ways to learn. Learning styles are features of organization and personality which are acquired in different places and ways such as, school, home and general society.

Styles are theoretical concepts that help to clarify the teaching- learning process. They are potentials in the performance of each student that persevere throught teaching techniques and experiences. Gregorc (1979)

Dunn and Griggs (1988) Learning style defines the way of how the environment of a classroom would be prepared according the requirements of the learners to get a best learning's atmosphere. It advises the ways in which students concentrate in a best way alone, with other people, with different kinds of teachers, or in a combination thereof. It advises the skills through which students incline to recall hard information in an easy way by hearing, speaking, seeing, using, writing, or notetaking, experiencing, or also, a combination of these. Learning styles also considers motivation, on task persistence or the necessity for different assignments simultaneously, the types and amount of structure required, and conformity versus nonconformity levels.

Revilla (1998) argues, "finally, some characteristics of learning styles: are relatively stable, although they may change; they may be different in different situations; they are susceptible 
of improvement; and when to students are taught according to their own learning style, they learn more effectively".

According Tobias (1995), there are reasons that teacher should know about children's learning styles:

- If you know your student's learning styles, you'll be better prepared to guide into the learning process.

- Most parents assume their children acquire the new knowledge according their learning styles. For example, if the parents are kinesthetic learners, it's not at all uncommon for them to suppose that their kids to be kinesthetic learners, too. However, children develop different learning styles than their parents and their siblings. if the parents understand the learning styles of their children in a fast way they can connect with them in a meaningful and effectively learning and also they can teach with great successfully.

- Parents have to be prepared to choose a good curriculum into the home.

- Parents can choose a curriculum without know the learning styles of their children. It will be an adequate job to obtain a good education for them, however it can not a significant education in their education. After parents know the learning styles of their children, you will choose a great curriculum that adapt to their necessities and you can be confortable with your decision.

- Finally, parents will recognize the way how your children understand to others.

- Sometimes children feel unsatisfied because they do not obtain a good communication with the society. Parents to understand their children, first they should know their different learning styles, it will benefit them to obtain a good communication with the society in their life.

Learning styles are important because it allows to know specifically the way of learning of each student thus teacher can teach more effectively to get meaningful learning. The teacher need to prepare the best curriculum according the necessities of each students based on learning styles to that students can use the English language according their level in the best way within the society. When the students recognize their learning styles, they feel prepare to understand and communicate with various person.

Kolb (1985) mention four principle groups of learning styles. The types are not inflexible and students may lead to one or another side in between them.

- Diverging

- Assimilating

- Converging

- Accomodating 
Main kinds of Learning Styles were established by Peter Honey and Alan Mumford, constructed in the Kolb's job, so they found four main learning styles or favorites: Activist, Theorist, Pragmatist and Reflector. All learning styles are mentioned by these authors to figure out what learning style have each student. So facilitating the fast learning and increase the thoughts each learner must have:

- comprehend their learning style

- try to find out new chances to study throught usage that style

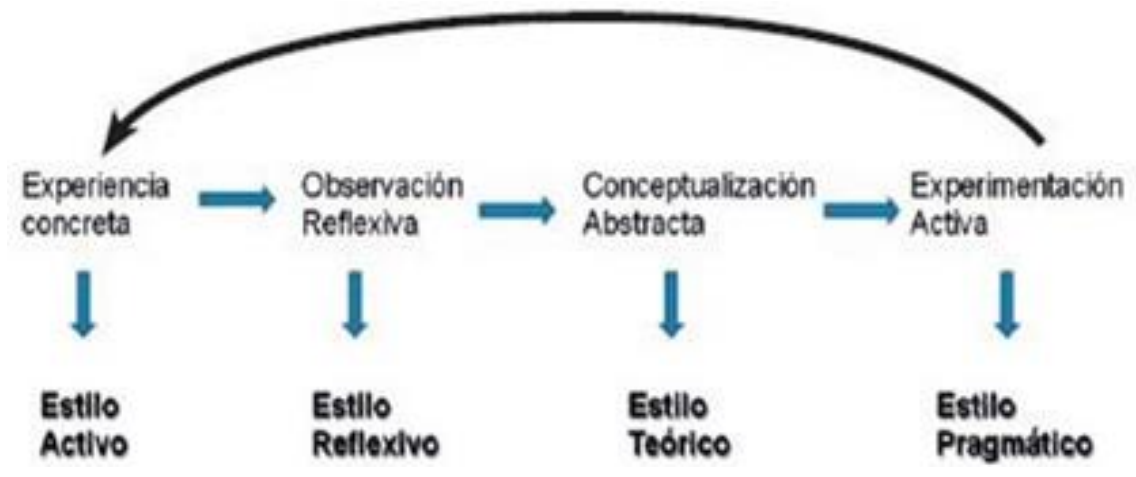

Image1 . Honey \& Mumford (1982) Learning Styles

These learning ways can permit the best learning process how the teacher teaches and how the student learns, so facilitate the gather of new information to students.

Honey and Mumford (1995) argues that, "students usually find these self-review activities informative and helpful, enabling them to engage more effectively in the seminars. However, there is a danger that ideas introduced in study skills modules can become detached from the core elements of an economics degree if they are not overtly reinforced by seminar leaders". "Assimilation is a cognitive process that manages how we take in new information and incorporate that new information into our existing knowledge" (Jean Piaget, 1988), so a person develops skills, attitudes and consistent values. For example, when a young child learns the word dog for the family pet, he eventually begins to identify every similar-looking canine as a dog. The child has extended his learning, or assimilated, the concept of dog to include all similar 4-footed friends.

Therefore, the assimilation in the process of teaching-learning of the students of Noveno and Décimo de Educación General Básica is vital to the retention of content and the proper development of the skills to be developed at this stage where they acquire good study habits and learning that will affect them for all their life.

\section{Methodology}

Qualitative method to be used: 
- Ethnographic.- It is a systematic process that is studied in a natural context. In this research, Documentary and Field research was applied.

- Field research.- The information or data was collected at "Liceo Policial Chimborazo" where the reviewed event occurs.

- Documentary.- The purpose was to extend and deepen the knowledge collected the data and used proper handling books, papers and printed documents from Universidad Nacional de Chimborazo.

- No experimental.- It was done without of variables.

This research is of qualitative type because it can be explained through existent theories using data collection that contribute with this research.

This research was Exploratory. It was determined throught observation method if a theory can be explained in base on currently existing theory with the data collection, it was exposed the information to get significant generalization that contribute with the investigation.

The population is relatively small; for this reason, was not necessary to take a sample therefore this study was made up of 2 Teachers, 33 Students of Noveno Grade and 19 Students of Décimo Grade, given as result 54 beneficiaries in Unidad Educativa "Liceo Policial Chimborazo" during school year 2015-2016. This group was choosed because we evidenced during the pre-professional practices the existence of a low level of English learning. Students of Noveno and Decimo grade have problems at the moment to acquire a new knowledge because teacher and students do not know the learning styles to develop their skills and abilities into the English subject. Their principal necessities are to know their learning styles and facilitate the use of adequate methods and techniques according to domain of each student for obtain a meaningful learning during the teaching-learning process.

The population is small therefore no sample is applied consequently; the work is involved with anyone indicated in the research process.

This research belong to Methodology area. The same was chosen because Methodology is the systematic and theoretical analysis of the methods applied to a field of study. It comprises the theoretical analysis of the body of methods and principles associated with a branch of knowledge.

In Methodology area the learning styles are very important because they are physiological, cognitive and affective characteristics that a student has to assimilate the knowledge using different abilities. In this research was investigated the specific problem "teachers and students do not know the learning styles, for this motive they do not have a good assimilation of knowledge at English language". 
The first step was requested authorization to the authorities at "Liceo Policial Chimborazo" Institution, after that our investigation title was approved in h-consejo, we requested in the career direction the office directed to the main authority of that Institution, which gave us the authorization in order to perform the field research. We did not have inconvenience in this process as the authorities of the institution gave us the approval to carry out this investigation.

The authorities gave us a specific time to apply the evaluation instruments to teachers and students, in this time we can observe the students in active way during the class. They performed very happy and very active; the student developed some questions to teacher.

There was some main aspects that were observed such as; the use of the learning styles, techniques and methods according the learning styles, level of the assimilation knowledge. To be realized this project we needed to know if the teachers and students know the learning styles for a good knowledge's assimilation.

This research verified that teachers and students did not know the learning styles obtaining a low level of knowledge's assimilation in the English subject. The information was obtained from teachers, students, books and internet.

The technique that was applied in this research is survey used to gather the necessary information.

- Survey: This technique helped us to gather information from students and teacher, the Unidad Educativa about the problems. Also it allowed to know the degree of feasibility that had the research proposal.

The instruments applied to be the questionnaire, where it was recorded the relevant aspects about learning styles and assimilation of knowledge that will be investigated.

- Questionnaire: It is a group of questions in a write way to get information about of this research from different point of views. It was used with students and teacher of Noveno and Décimo de Educación Básica de la Institución Educativa "Liceo Policial Chimborazo" to obtain specific information for each student and teachers according our research's topic.

To determine the analysis of the collected information will be used the following techniques:

- Review the information obtained of the survey applied to the teachers and students at "Liceo Policial Chimborazo" during 2015-2016 school year.

- Analysis showing the results obtained of the survey.

- Conclusions and Recommendations were given according to the results of analysis of the survey. 


\section{Method}

- Scientific method: because it is a systematic rational and logical process by which begin on the definition and delimitation of the problem, specifying clear and concrete objectives, gathering reliable information.

- Inductive method: because it seeks to know the reality and apply theoretical concepts in the research problem.

\section{Results}

This research was developed at the Unidad Educativa "Liceo Policial Chimborazo" with Noveno y Decimo de Educación Básica General in 2015-2016 school year in order to explore the learning styles in the knowledge's assimilation.

Table 1. Survey to the teachers

\section{$\begin{array}{lll}\text { OBJECTIVES INFORMATION ANALYSIS } & \text { ANA }\end{array}$}

1.- To determine if the learning styles influence in the assimilation of knowledge of the subject of English, in the students of Noveno and Décimo año de Educación Básica at Institución Educativa "Liceo Policial Chimborazo" during the school year 20152016.
The analysis shows that within the student group of Noveno and Decimo de Básica predominate the laerning styles active and reflexive. Therefore teachers should use techniques and strategies related to these learning styles to facilitate the acquisition of English language skills.
2.- To identify the learning styles used in the English subject, for the assimilation of knowledge in the students of Noveno and Décimo año de Educación Básica at Institución Educativa "Liceo Policial Chimborazo".
1.- Of the following Learning styles which more prevail for achieve a good assimilation of knowledge in the subject of English within your group of students?
The results show that the 2 teachers do not have a deep knowledge about learning styles used in the process of learning of their students; the unknow makes to difficult to recognize learn-
2.- Do You Know About Learning Styles used in the process teaching and learning of English as a subject? ing styles that each student has and likewise the interaction and assimilation knowledge into the subject of English Language. The learning styles are essential to improve the quality study of the students because they allow them motivate in the teachinglearning process. 
3.- To analyze the level of assimilation of knowledge with relation to learning styles used in the English subject in the students of Noveno and Décimo año de Educación Básica at Institución Educativa

3.- How often do you use the techniques described below to teach English? Brainstorming, project development, directed study, forum and role play.
The results show us that the 2 teachers think that the success of learning in this school year is fairly satisfactory revealing that the planted objectives for this year were not met with success in the area of English Language.

"Liceo Policial Chimborazo" to Project their improvement.

4.- To establish the different learning styles in the assimilation of knowledge with relation to learning styles used in the English subject in the students of Noveno and Décimo año de Educación Básica at Institución Educativa "Liceo Policial Chimborazo" during the teaching - learning process.
Students do not receive the English 4.- How often do you relate the meth- classes in a good manner for this reaodology with Learning Styles? son the knowledge' assimilation is fairly satisfactory.
5.- How often do you updated about the thematic of study within the teaching-learning process?
The analysis shows that one teacher sometimes diagnosed learning styles of their students and another teacher never. This result shows us that teachers do not use the appropriate techniques and methodologies for the group of students as each student has different learning style and not all assimilate new knowledge in the same way. Is necessary that teachers use the adequate techniques for obtain a good assimilation of Knowledge.

6.- How Do you consider that the level of success achieved in the assimilation of knowledge in the process of teaching-learning of English Language in this school year to be?

7.- How often the obstacles that are described below prevailing in the learning process of the subject of English? Lack of motivation, tiredness, lack of appropriate teaching materials and use of traditional methods.

8.- Have you diagnosed the Learning Style of your students?

SOURCE: Survey applied to teachers BY: Abigail Garrido and José Sinaluisa 
Tabla 2. Learning Styles in students

\begin{tabular}{lcc} 
ITEM & FREQUENCY & PORCENTAGE \\
\hline Theoric/ Reflexive & 11 & $33 \%$ \\
Active/ Pragmatic & 7 & $2 \%$ \\
Theoric/Pragmatic & 3 & $1 \%$ \\
Pragmatic/Reflex- & 20 & $61 \%$ \\
ive & 4 & $1 \%$ \\
Active/Theoric & 7 & $2 \%$ \\
Active/ Reflexive & $\mathbf{5 2}$ & $\mathbf{1 0 0 \%}$ \\
TOTAL &
\end{tabular}

SOURCE: Survey applied to teachers

BY: Abigail Garrido and José Sinaluisa

ANALYSIS: The most of the students have Pragmatic/ Reflexive Learning Styles in this grade that permit to acquire the new knowledge's assimilation through activities according to these styles. They permit that students use the skills into the English language to obtain a meaningful learning in academic process and students can use the language in real world.

\section{Conclusiones.}

- The learning styles influence in the assimilation of knowledge becuase they are cognitive and physiological features that permit the learner to get the meaningful learning using the skills or abilities to study a second language in this case English language.

- There is different kind of learning styles such as; active, pragmatic, theoric and reflective. In this group of students exist a high necessity to know the learning styles and relationship with adequate strategies and methods to improve teaching- learning in the English subject so achieve with succsess the posed goals in Noveno and Decimo de Educación Básica General de la Institución Educativa "Liceo Policial Chimborazo"

- There is a low level of assimilation of knowledge with relation to learning styles because teacher and students do not know learning styles, it can not permit teacher help to that students have an high level of learning at English subject.

- The most of the students in Noveno and Decimo de Educacion Basica have Pragmatic /reflexive learning styles which are useful to increase the knowledge into the students and describe what level of assimilation has each student to learn a second language in the learning process. 
ISSN: 2600-5859

WWW.concienciadigital.org

References bibliographical.

Dunn, S and Griggs, A. (1988) Learning Styles. Date: March/15/2016 Retrieved from: http://www.openaccesslibrary.org/images/BOS134_Selma_Kara.pdf

Franzoni, A. L., Assar, S., Defude B. \& Rojas, J., (2009) "Student Learning Styles Adaptation Method Based on Teaching Strategies and Electronic Media," 2008 Eighth IEEE International Conference on Advanced Learning Technologies, Santander, Cantabria, pp.

778-782.

doi: 10.1109/ICALT.2008.149

Gregorc, J (1979) Learning Styles. Date: March/15/2016 Retrieved from: http://old.fltrp.com/download/06071807.pdf

Honey, P. \& Mumford, A. (1995) Honey and Mumford.Date: June/ 20/2016. Retrieved from:http://www2.le.ac.uk/departments/gradschool/training/eresources/teaching/the or ies/honey-mumford

Kneefe, J. (1988) Application, Reliability and Validity of the Index of the Learning Styles. Date: March/15/2016. Retrieved from: http://www4.ncsu.edu/unity/lockers/users/f/felder/public/ILSdir/ILS_Validation(IJE E).pdf

Kolb, D. (1984). Learning Styles and language learning. Date: March/23/2016. Retrieved from: http://englishmagicbox.com/site/learning-styles/

Piaget. J. (1988) Assimilation and Piaget: Definition, Theory \& Process. Date: March/19/2016. Retraived from: http://study.com/academy/lesson/assimilation-andpiaget-definition-theoryprocess.html

Poma, J. (2014). Análisis de los estilos de aprendizaje del idioma inglés en los alumnos de primer año de bachillerato del Colegio, Capitán Edmundo Chiriboga, años 20122013. unach, 2014.

Revilla, D. (1998) Estilos de Aprendizaje. Date: March/16/2016. Retrieved from: http://www.monografias.com/trabajos91/los-estilos-aprendizaje/losestilosaprendizaje.shtml

Tobias, C. (1995) The Way They Learn. Date: June/ 20/2016. Retrieved from: http://www.sonlight.com/learning-styles/

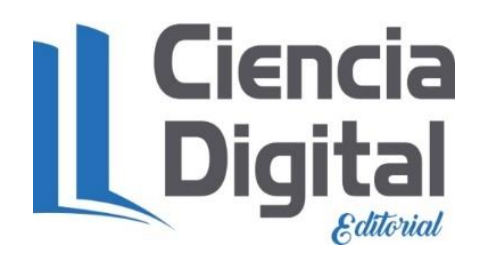

Creatividad, Diseño e Innovación

Página 27 
ISSN: 2600-5859

PARA CITAR EL ARTÍCULO INDEXADO.

Garrido Valle, A. D., Basantes Arias, E. A., \& Escobar Murillo, M. G. (2020). Exploración de los estilos de aprendizaje de inglés y la asimilación del conocimiento del estudiante. ConcienciaDigital, 3(1.1), 17-28. https://doi.org/10.33262/concienciadigital.v3i1.1.1129

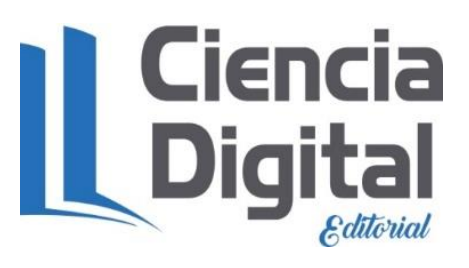

El artículo que se publica es de exclusiva responsabilidad de los autores y no necesariamente reflejan el pensamiento de la Revista Conciencia Digital.

El artículo queda en propiedad de la revista y, por tanto, su publicación parcial y/o total en otro medio tiene que ser autorizado por el director de la Revista Conciencia Digital.

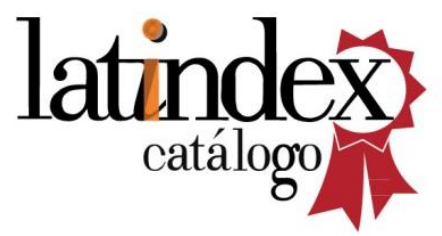

